\title{
The Historical Memory of Ethnic Poles in Belarus: A Cultural and Ideological Palimpsest
}

\begin{abstract}
This article examines the main characteristics of the historical memory of Poles in Belarus, allowing to speak about the special image of the past within this ethnic group. The canon of historical and cultural figures is analyzed, as well the relationship between historical grand narrative and family memory that creates a trend of "escape" from the rigid interpretations of the past.
\end{abstract}

Keywords: historical memory, ethnic identity, cultural canon, historical narrative

During a press conference at the National Library of Belarus held on 8 September 2010, the main results of the 2009 census in the Republic of Belarus were announced. According to the presented information, there had been a significant decrease in the number of representatives of national minorities in the country, compared with the results of the previous census held in 1999. This applies to Russians, Poles, and Ukrainians. Thus, in 10 years the number of Poles in Belarus decreased from 396 to 295 thousand people (i.e. 25.5\%). The decrease of the number of Poles in the country had been noted when comparing the results of previous censuses, but it never happened at such a rapid pace. This sharp decrease in the number of Poles in the last 10 years can not be fully explained by the all-Belarusian demographic crisis related to the falling birth rates and population aging. Obviously, this period was characterized by accelerated assimilation processes leading to the fact that representatives of other nationalities started identifying themselves as Belarusians. Despite the objective nature of the process, which is mainly associated with the consolidation of the independent Belarusian state and the consolidation of national identity by civil grounds, it is clear that such assimilation would not be possible without the critical state of the Polish ethnic identity in Belarus. 
In our case, we will try to analyse the main features of the historical memory of Belarusian Poles considering the common statement in modern science that memory is the foundation for building a special identity.

First, we would like to identify the main reasons by which the historical memory of Belarusian Poles may differ from the canon of the Belarusian national memory. This distinction is prescribed by the nature of the community of Belarusian Poles:

1. The community of Poles in Belarus primarily appeared not as a result of migration from Poland, but as a result of a voluntary Polonization of the local population (adoption of Catholicism and the Polish language gave the opportunity for upward mobility);

2. For centuries, a connection between religious and ethnic identity maintained in the border areas between Catholicism and Orthodoxy, and the relics of this can be found even in our time. Thus, there is still a stereotype "Catholic=Pole";

3. As a result, the identity of local Poles in Belarus has many hybrid features; it has no solid separation lines from Belarusians (the phenomenon of dual identity is quite common, only $17 \%$ of Poles recognize Polish as their native language, etc.).

It follows that Belarusian Poles have to balance between the two strategies in their social interactions:

1. Reject the complete assimilation and promote the ethnic and cultural identity of their group, as the full assimilation of the canon of national memory in the Belarusian version would blur the boundaries of the Belarusian Poles' identity and lead to their gradual disappearance among the dominant ethnic group;

2. Find ways of mutual understanding and conflict-free coexistence, including through the knowledge and acceptance of the codified version of the Belarusian past.

The difficulty is to find the balance between these two strategies, as implementation of any of them alone could lead either to a social unrest or to a loss of the ethnic identity. It should be stressed that these strategies are distinguished from the outside, analytically. In reality, they are rarely conceptualized in this way and are implemented through the routine of daily life with the help of certain methods, a segregation of different levels of social action with differentiated logics.

1 A. Engelking, Jak katolik to Polak. Co to znaczy?, [in:] Wschodnie pogranicze w perspektywie socjologicznej, ed. A. Sadowski, Białystok 1995, pp. 138-146. 
Thus, the Polish origin is usually not advertised in the public space except for festival representations, but is one of the most important sources for family education.

Based on the work of various sociological and ethnographic studies, we can identify several key sources for forming the collective memory of Belarusian Poles:

1. Educational system (especially high school) which consistently translated firstly Polish, then Soviet, and now Belarusian historical narratives. Somewhat more complicated is the case with the Polish schools in today's Belarus, this aspect perhaps requires a separate study;

2. Mass media (newspapers, radio, television). Now, of course, Belarusian media have the predominant influence on the consumption of information by Belarusian Poles, but Polish media also broadcast in Western Belarus, and they are also an important source of knowledge about the past and the present of Poland (and, accordingly, about the image of Belarusian Poles formed by the Polish state);

3. Family legends that have a limited time horizon, 80-100 years, but grasp the fateful events that directly affected the historical fate of Belarusian Poles (beginning of World War II, Stalin's repressions).

In this report, I will rely primarily on the results of the survey among Poles in Belarus carried out by the Institute of Sociology, Belarusian National Academy of Sciences, in November-December 2008, questionnaire, sample is 787 respondents in all regions of Belarus. This data suggests that the history of Poland (as a common narrative that unites the historical homeland and all Poles scattered in time and space) is an important symbol in which Belarusian Poles take a strong interest.

Let's illustrate this thesis by an example of how representatives of different age groups of Belarusian Poles are interested in the history of Poland (Table 1). It should be noted that in this case the "interest" is considered only in a symbolic way, showing the orientations of individuals that may not appear in the actual social practices.

Table 1. The interest in the history of Poland among different age groups of Belarusian Poles (\% by column)

\begin{tabular}{|l|c|c|c|c|}
\hline \multirow{2}{*}{$\begin{array}{l}\text { Are you interested } \\
\text { in the history of Poland? }\end{array}$} & \multicolumn{3}{|c|}{ Age groups } & \multirow{2}{*}{ Total } \\
\cline { 2 - 4 } & $\mathbf{1 6 - 2 9}$ & $\mathbf{3 0 - 4 9}$ & $\mathbf{5 0 +}$ & \\
\hline Yes & 14.7 & 18.4 & 29.7 & 20.5 \\
\hline Rather yes & 34.2 & 36.1 & 33.5 & 34.8 \\
\hline Rather no & 39.8 & 36.4 & 27.4 & 34.9 \\
\hline No & 11.3 & 9.1 & 9.4 & 9.8 \\
\hline
\end{tabular}


Thus, more than half of the respondents are interested in the history of Poland. It may seem that this is not so much, but if we compare this data with the results of the surveys conducted regularly in Poland ${ }^{2}$, we can see that there are no significant differences in the intensity of the symbolic interest between the Poles in Poland and the Poles in Belarus (Table 2). While in Belarus about $55 \%$ of Belarusian Poles are interested in the history of Poland, the dynamics of the interest in history in the neighbouring state varies between 59\% (in 1987) and 57\% (in 2004).

Table 2. The interest in history among residents of Poland (\% by column)

\begin{tabular}{|c|c|c|c|c|c|c|}
\hline \multirow{3}{*}{$\begin{array}{l}\text { How would you } \\
\text { define your interest } \\
\text { in history? } \\
\text { Very high } \\
\end{array}$} & \multicolumn{6}{|c|}{ Research } \\
\hline & \multicolumn{2}{|c|}{ CBOS, 1987} & \multicolumn{2}{|c|}{ OBOP, 1996} & \multicolumn{2}{|c|}{$\begin{array}{c}\text { ISP PAN/ PENTOR, } \\
2004\end{array}$} \\
\hline & 4 & \multirow{2}{*}{16} & 7 & \multirow{2}{*}{21} & 5 & \multirow{2}{*}{19} \\
\hline High & 12 & & 14 & & 14 & \\
\hline Average & 44 & 44 & 43 & 43 & 39 & 39 \\
\hline Low & 28 & \multirow{2}{*}{40} & 22 & \multirow{2}{*}{36} & 28 & \multirow{2}{*}{42} \\
\hline No interest & 12 & & 14 & & 14 & \\
\hline
\end{tabular}

However, if we return to the analysis of data for the various age groups of Belarusian Poles (Table 1), the most important result arising from the comparison is a serious loss of interest in the history of Poland among the younger generation. This is especially true with regard to the accentuated symbolic interest, when a respondent selects the clear statement "Yes". The share of Belarusian Poles who chose this option is $29.7 \%$ among the older generation, which falls by half among the younger generation (14.7\%). That is, the value of the particular history as a component of the Polish identity is much smaller for the younger generation of Belarusian Poles. Meanwhile, the interest in Polish history is roughly equal among rural and urban residents - this fact we will use a little further.

But while the history of Poland is a subject of interest at least for the majority of Belarusian Poles, the personal assessment of the real knowledge of Polish history looks much more sceptical (Table 3).

2 A. Szpociński, Formy przeszłości a komunikacja społeczna, [in:] A. Szpociński, P.T. Kwiatkowski, Przesztość jako przedmiot przekazu, Warszawa 2006, pp. 7-66. 
Table 3. Personal assessment of the knowledge of Polish history among Belarusian Poles with different levels of education ( $\%$ by column)

\begin{tabular}{|l|c|c|c|c|c|}
\hline \multirow{2}{*}{$\begin{array}{l}\text { Please assess how well } \\
\text { you know the history } \\
\text { of Poland }\end{array}$} & $\begin{array}{c}\text { Primary } \\
\text { and } \\
\text { incomplete } \\
\text { secondary }\end{array}$ & Secondary & $\begin{array}{c}\text { Secondary } \\
\text { vocational }\end{array}$ & $\begin{array}{c}\text { Higher and } \\
\text { incomplete } \\
\text { higher }\end{array}$ & \multirow{2}{*}{ Total } \\
\cline { 2 - 5 } $\begin{array}{l}\text { I know Polish history } \\
\text { rather well }\end{array}$ & 2.8 & 3.6 & 5.5 & 13.7 & 7.4 \\
\hline $\begin{array}{l}\text { I know the key dates and } \\
\text { events, but not much else }\end{array}$ & 14.8 & 16.6 & 17.8 & 30.5 & 21.4 \\
\hline $\begin{array}{l}\text { My knowledge of Polish } \\
\text { history is fragmentary } \\
\text { and unsystematic }\end{array}$ & 50.0 & 43.5 & 50.2 & 39.7 & 45.0 \\
\hline $\begin{array}{l}\text { I know almost nothing } \\
\text { about the history } \\
\text { of Poland }\end{array}$ & 30.6 & 35.2 & 25.6 & 15.3 & 25.2 \\
\hline Other & 1.8 & 1.1 & 0.9 & 0.8 & 1.0 \\
\hline
\end{tabular}

The most significant contrast in the personal assessment of the knowledge of Polish history is seen among the groups with different levels of education. This trend does not seem surprising. Belarusian Poles in their assessment of historical knowledge retain the classic tendency for the modernist society - to assess the level of competence in a field of knowledge based on the level of education.

Another major difference is noted between urban and rural residents: $9.1 \%$ of the urban population know the history of Poland rather well compared to $4.5 \%$ of the rural population, while the interest in Polish history is expressed almost equally. As we can see, there is a certain gap between the expression of the interest and its actualization, which may be caused by the natural differences between the educational opportunities and the availability of information in the city and in the countryside.

But in this case, more important is the difference between the declared interest and the real knowledge of Polish history, which can not be only due to the information barriers. Due to the fact that any restrictions on access to the information from Poland are removed today, and considering the development of the modern information technologies that contributes to a fairly free access to information ${ }^{3}$,

3 However, only $14.8 \%$ of Belarusian Poles use the Internet as a source of knowledge about Poland. 
it can hardly be argued that there are serious institutional barriers for implementation of that interest. The statement of interest in Polish history is rather of declarative nature, an expression of loyalty to the ethnic group which does not necessarily require practical implementation. The reluctance to make some effort for acquiring knowledge about the history of Poland indicates that, despite the symbolic importance of historical memory as a component of ethnic identity, the memory of the past for Belarusian Poles is not placed in the centre of formation of the ideas about their community.

Let's try to point out the reasons for such peripheral status of historical memory for Belarusian Poles. Quite often, the memory of social groups is formed by the interaction of the "grand" narratives (national, state versions of history implemented in the practice of social institutions) and communicative memory transferred mainly through the family channels (which in the case of Belarusian Poles has ethnic and religious specificity).

In the case of Belarusian Poles, the formation of the group memory is much more complicated, because here several "grand" narratives "confront" each other, so in the absence of hegemony they all operate in a weakened form. Consequently, the role of communicative memory increases, which under normal conditions has inferior function of filling the frameworks formed by the "grand" narratives with biographical content.

We distinguish the following narratives, the presence of which has an impact on the formation and peculiarities of the historical memory of Belarusian Poles:

1. Polish national narrative that sees Belarus as Kresy Wschodnie (Eastern Borderlands) and forms national identity by strict ethnic and cultural canons (exclusive religion, language, memory). This narrative dominated during the Second Polish Republic (1921-1939), then it remained - in a more rigid form - in the claims of Polish emigration for return of the eastern border of the Polish state to the resolutions of the Peace Treaty of Riga. In the modern Polish state this narrative exists in a much milder form (nostalgia for a lost heritage) and generates another version of cultural and civilizing missionary activities. In this narrative, Belarusian Poles are treated as fellow citizens who - due to the tragic fate of the Polish state - appeared outside their homeland, but their higher mission remains the preservation of "Polishness" (with the connotations of a higher, noble culture);

2. Soviet historical narrative which was focused on formation of a general Soviet identity, resulting in ethnic differences losing their fundamental importance and being subject to disappearance in the communist future, whereas for the normative description of the present, the myth of "friend- 
ship of peoples" was used (this way of describing history dominated in the Soviet Union);

3. Belarusian national narrative based on the paradigm of revival of the Belarusian nation as the one returned to the traditions of statehood. In this narrative, Belarusian Poles play a dual role: on the one hand, they are considered as the lost "ours", i.e. same Belarusians who formally took the Polish identity but whose essence still remains "Belarusian"; on the other hand, they may be dangerous for the Belarusian national state as potential agents under the influence of Poland - a historically ambivalent neighbour with a powerful expansionist potential;

4. Belarusian state narrative which possesses a significant share of continuity with the Soviet one, and, in fact, represents a moderate synthesis of the national and Soviet strategies of describing the past.

Over the past decades, the following basic principles of the Belarusian Soviet historiography found new life and became the basis for the official narrative of Belarusian history:

1. Axiomatic recognition of the East Slavic character of the Belarusian people (from their belonging to the Russian civilization and Orthodox culture many settings for description of different events are derived - firstly, emphasizing the positive nature of the historical relations of the Belarusian and Russian peoples);

2. A positive image of the Soviet past in which bases for the modern Belarusian statehood were formed;

3. The fundamental nature of the victory in the Great Patriotic War as a key event in the history of Belarus, the main legitimizing myth for the young Belarusian state.

On the other hand, national historiography, from which the general teleology of formation of the Belarusian statehood was borrowed, has become another important source for the official image of history of the Republic of Belarus, but with certain modifications, i.e. removal of the most radical points which could get in conflict with the abovementioned narrative models of the Soviet origin.

Meta-narratives define a common framework for understanding and comprehension of history on a large scale (national or supranational state), building a linear scheme of history development, assigning it with meaning and purpose (again, mostly from the state positions). For most people, "grand" narratives exist in parallel with their personal and family history, where emotionally significant events are deaths of the loved ones, migrations, the periods of material prosperity or starvation, etc. But personal understanding of the past may conflict with the 
"grand" narratives. Thus, those Poles who had all their property confiscated and who were sent to Siberia in 1939, as well as their families, are unlikely to be particularly enthusiastic about the words of "reunification of the Belarusian people" which are used to describe the events of that period in the Soviet and Belarusian "grand" narratives.

The frequent changes of government in Western Belarus which is most densely populated by Belarusian Poles led to the fact that the state itself and its institutions were seen as alienated, especially by the older generation. This is clearly proven by the results of field studies using the methodology of oral history conducted in the western border area of the Republic of Belarus by the Centre for Studies on the Classical Tradition at the University of Warsaw ${ }^{4}$.

Accordingly, under these conditions, historical narratives of the power could hardly qualify for the full acceptance and the undeniable value for the local population.

Given the complex nature of the interaction of "big" narratives, supplemented by the specific nature of the communicative memory, stable and consistent views of the past are hardly to be expected from Belarusian Poles. In such confusing and contradictory social conditions, the collective memory could be formed only as a bricolage - i.e. borrowings of various elements from different systems of knowledge, change of their fixed values and mixing in some single whole which does not have a rigid structure, but is enough to validate the orientations in the social space.

Consequently, the ideas borrowed from different (and competing) "grand" narratives can coexist in the historical memory of Belarusian Poles. Their antagonisms and contradictions disappear due to the "softening" of the theses and perceiving them as external narratives that do not affect the nature of the everyday life of Belarusian Poles.

But it leads to the blurring of historical memory, where the single canon is extremely limited, and there is virtually no content. Related to this is also the "uselessness" of knowledge of the national history, as evidenced by the personal assessments made by Belarusian Poles when evaluating their knowledge of Polish history.

Poor knowledge of Polish history and culture can also be seen in the answers to the open questions relating to the key persons. When asked to name the famous people that had had the most significant influence on the formation of Polish culture, $41.8 \%$ of the surveyed Poles were not able to answer ${ }^{5}$; the most well-

4 Pogranicza Biatorusi w perspektywie interdyscyplinarnej, ed. E. Smułkowa, A. Engelking, Warszawa 2008.

5 This and the following questions were open, no pre-formulated options were offered. 
known were Adam Mickiewicz (30.7\%) and Eliza Orzeszkowa (13.5\%) - born in the same Grodno region, Litwini, who are firmly included in the pantheon of Belarusian culture too.

Even more difficulty caused the question of the historical figures that had had a positive influence on Polish history $-56.2 \%$ of the respondents were not able to answer. The leading ones among the mentioned figures are John Paul II (18.7\%), Lech Wałęsa (14.5\%), Józef Piłsudski (10.7\%) and Tadeusz Kościuszko (6.5\%).

Quite interesting is to compare the pantheon of Polish historical figures recorded among Belarusian Poles with the results of sociological research in Poland ${ }^{6}$.

Table 4. Personalities of Polish history recognized as a cause for pride

\begin{tabular}{|l|c|l|c|l|c|}
\hline \multicolumn{2}{|c|}{1987} & \multicolumn{2}{c|}{1996} & \multicolumn{2}{c|}{2003} \\
\hline Personalities & $\%$ & Personalities & $\%$ & Personalities & $\%$ \\
\hline Tadeusz Kościuszko & 35.2 & Józef Piłsudski & 33 & John Paul II & 42.9 \\
\hline Władysław Jagiello & 13.8 & Lech Wałęsa & 19 & Józef Piłsudski & 23.0 \\
\hline Nicolaus Copernicus & 13.3 & John Paul II & 16 & Lech Wałęsa & 16.4 \\
\hline Józef Piłsudski & 12.5 & Tadeusz Kościuszko & 10 & Tadeusz Kościuszko & 14.4 \\
\hline John Paul II & 11.4 & Władysław Jagiello & 8 & Nicolaus Copernicus & 10.4 \\
\hline Jan III Sobieski & 9.8 & Casimir the Great & 8 & $\begin{array}{l}\text { Marie Skłodowska- } \\
\text {-Curie }\end{array}$ & 6.9 \\
\hline Adam Mickiewicz & 9.7 & Jan III Sobieski & 5 & Adam Mickiewicz & 6.5 \\
\hline
\end{tabular}

Again, as we see, there are no significant differences; almost the same list of figures is represented, which indicates a high degree of integrity and formalization of the Polish national canon that is also being translated outside the country. Though the list of the personalities is almost the same, the most important difference is the degree of their representation for Belarusian Poles. The fixed fact that in Belarus only $43.8 \%$ of the respondents were able to answer this question indicates that the canon, despite all its integrity, is either not absorbed or ignored by the majority of Belarusian Poles.

The questionnaire contained the question of who had a negative influence on the history of Poland. The results show that this formulation is not productive, $92.4 \%$ of the respondents were unable to answer this question. Among the few answers only the names of modern Polish politicians are found: Kaczyński - 1.9\%, Wałęsa $-1.4 \%$, and Jaruzelski $-1.1 \%$. However, the identified trend is not sur-

6 P.T. Kwiatkowski, Czy lata III Rzeczypospolitej byty "czasem pamięci"?, [in:] Pamięć zbiorowa jako czynnik integracji i źrodto konfliktow, ed. A. Szpociński, Warszawa 2009, pp. 125-166. 
prising, since the canon of historical memory is formed in the first place as a cause for pride, allowing to set a positive emotional connection with the history of one's own community. Therefore, the greatest importance belongs to the pantheon of great figures who through their heroic deeds and extraordinary creativity gained fame not that much for themselves, but rather to the community they represent. Certainly, tragedies and hard times which are cementing collective identity also play an important role for historical memory. But most often, the responsibility for such events is projected outwards, to other peoples who play the role of "others" or "foreigners" in the process of forming the self-image for an ethnic group or nation. However, Belarusian Poles do not resort to this trick - Catherine II, Hitler and Stalin, who are the favourite "enemies" in the official Polish narrative, got only few individual responses. Here, the clearest tendency is the one of avoiding any conflict interpretations of the historical past, which may adversely affect the Belarusian Poles' neighbourliness with other nations.

This trend of escape from the complexities of understanding the tangled knots of the historical past manifested itself in the answers to the problematic question relating to annexation of Western Belarus to the BSSR after the events of 17 September 1939. We shall recall that up to that time, in accordance with the resolutions of the Peace Treaty of Riga (1921), Western Belarus and Ukraine were part of the Second Polish Republic which considered these territories as its Kresy Wschodnie, i.e. Eastern Borderlands. The Soviet Union used the Nazi attack on Poland on 1 September 1939, in order to annex these lands, thus resuming the territorial integrity of Belarus and Ukraine.

The Polish historical narrative considers these events as a collusion between Stalin and Hitler, which led to the loss of Polish lands and the tragic consequences for the Poles in these areas.

The Soviet narrative considers these events in extremely positive way, as the events which put an end to the Polish nobility's exploitation of the local population and gave the opportunity for a reunion of the Belarusian people.

In the Belarusian historical narrative, the interpretations of this event bifurcate: widely spread is a positive evaluation which reproduces an almost unchanged Soviet version (now supported on the official level), but there are also alternative, more critical views. This way or another, the fact of reunification of the Belarusian people within the borders of one state is always considered positive?

Understanding of these events by Belarusian Poles remains controversial; most

7 D. Boćkowski, Wspótczesna historiografia biatoruska wobec 17 września 1939 roku, Dzieje Najnowsze, 2009, No. 3, pp. 165-169. 
of them (62.3\%) failed to give any assessment of this event, which again confirms the tendency of escaping from the conflict interpretations that we noted before. It can be assumed that the part of Belarusian Poles (13.6\%) which positively evaluates the events of 17 September is hyper loyal to the Belarusian national canon, sharing even those of its contradictory positions that are in conflict with the image of the past within the ethnic group. To some extent, those $62.3 \%$ who avoided to answer the difficult question can be included here.

At the same time, $20.7 \%$ of the respondents gave a negative assessment of the annexation of Western Belarus, though both in the Soviet era and in present-day Belarus these events have always been promoted in a positive way. Consequently, we can emphasize the existence of a special memory of Belarusian Poles, which does not conform to the official Belarusian version of these territorial changes that greatly influenced the fate of Poles in the former Kresy Wschodnie (but which does not dominate). It is interesting to consider the arguments that are used to substantiate the negative or positive assessment of these events.

To justify the policy of the Soviet authorities, the arguments based on the common interests of Belarus as a country are often used: "Belarus had to unite and become one republic", "reunification of the Belarusian people", "positive, because one republic must be within the same country". Obviously, a part of Belarusian Poles successfully acquires the vision of the historical past popular in the Belarusian society, which, however, is a completely natural process.

To justify the negative assessment, two basic types of reasoning can be singled out. The first of these is also appealing to the interests of Poland as a country: "negative, as it is a native Polish territory, and Russia took it from Poland", "agreement between Hitler and Stalin against Poland", "Poles should live in Poland". Iwona Kabzińska also stresses the manifestations of Polish patriotism in conversations that involve historical themes, but among representatives of the older generation, while they emphasize that the forming of such views was strongly influenced by parents and teachers. For example, a 63-year-old resident of the village Tartaki recalled that her father ("Catholic by blood and bone") was crying when on 17 September 1939, Soviet soldiers tore the Polish coat of arms off the school building, and then threw it to the ground and started to stomp on it $^{8}$. Again, we shall note that an important role in it was played by the school system in the Second Polish Republic which inculcated Polish patriotism, but such type of representation is clearly dying along with its bearers.

8 I. Kabzińska, Wśród „kościelnych Polaków”. Wyznacznik tożsamości etnicznej (narodowej) Polaków na Biatorusi, Warszawa 1999, p. 44. 
Much more frequent are the mentions of how these events have affected people's lives: "have they asked then how much grief and pain the people had?", "deprivation of property and family ties", "negative because of the dispossession of many people", "people were hurt", "grandpa had a shop in Brest, but after the annexation it was gone". Such arguments point to the existence of informal channels for transmitting the memory of the past, mainly through communication within the family. And the existence of such family tradition is another important reason to maintain the Polish identity in Belarus. Belarusian Poles consider family education an essential factor in maintaining the traditions of Polish national culture (69.3\%), and only religion has a priority in this respect (78.6\%).

To sum up this section, we can draw the following conclusions:

1. $\mathrm{n}$ the historical memory of Belarusian Poles, many different representations from different state traditions and epochs are piled up. The Polish historical narrative is only one of the sources of forming the historical memory of Belarusian Poles, existing side by side with the ideas of the past borrowed from other narratives.

2. For Belarusian Poles, the history of Poland acts as an important symbol that causes external loyalty. But the real knowledge of Polish history is not that great. Despite the fact that the Polish historical canon (events and personalities) is rather integral, which contributes to its successful reproduction, the majority of Belarusian Poles have either bad or no knowledge of it at all.

3. Thus, the Polish national narrative serves only one of several sources of knowledge about the past (and present) for Belarusian Poles; it is not used as a cementing and foundational factor for the ethnic group. Although this narrative strictly describes who Poles are (including who the Poles in Belarus are), and it would be easy to use as a "counter-memory" for building one's own identity politics. Under this option, the adoption of the Polish national version of history would promote a more rigorous socio-cultural division of Belarusian Poles and Belarusians and hinder the assimilation processes. But, as we see, the Polish historical canon is not an ultima ratio for the given ethnic group, and the historical memory of Belarusian Poles contains fragments of various "grand" narratives allowing to avoid memory conflicts with other ethnic groups, especially Belarusians.

4. A special role for Belarusian Poles is played by the family memory which contains and translates the knowledge of the past which is of particular importance on the family and local level (particularly important is the history just before and during World War II as well as immediately after the liberation of Belarus from the German occupation). Many scenes in this set of 
events and their interpretations have significant differences, and sometimes serious contradictions with the official narratives. But the family traditions and the state history do not enter into a dialogical relationship, continuing to exist at various levels. Thus, the historical memory of Belarusian Poles not only contains the evaluative schemes of different "grand" narratives, but also has a multi-layer structure resembling a palimpsest. 